\title{
Private Cost of Bachelor's Degree Programmes by Major Fields in Nigeria
}

\author{
Igot Ofem Bassey, $\mathrm{PhD}$ \\ Department of Educational Management \\ Lagos State University, Lagos, Nigeria \\ E-mail: igotofem@yahoo.com \\ Samuel Akinyemi, PhD, AIMM \\ Department of Educational Management \\ Lagos State University, Lagos, Nigeria \\ E-mail: akinyemisam2006@yahoo.com
}

Received: April 11, 2012 Accepted: April 26, 2012 Published: May 1, 2012

doi:10.5296/jse.v2i2.1621ＵRL: http://dx.doi.org/10.5296/jse.v2i2.1621

\begin{abstract}
Generally, undertaking a university education is an expensive investment and the high and increasing private cost of bachelor's degree programs in Nigeria which cuts across all income brackets has created a significant financial burden on families, particularly low and middle income households. This paper argues that given the varying costs of bachelor's degree programs by field of study, the knowledge of the average private cost can guide investment decisions and minimize wastages in the Nigerian education system. After an analysis of the private cost of bachelor's degree in public universities in Lagos state of Nigeria and comparing the variations in private costs by major fields of study using descriptive and inferential statistics (Analysis of Variance), this paper is of the view that given the escalating price of bachelor's education and the limited resources available to the middle and low income earners, prospective consumers of bachelor's education should effectively plan their investments in the fields that will yield highest rate of returns and minimize wastages in the education system.
\end{abstract}

Keywords: Private cost, Bachelor's degree, major fields, wastages and Nigeria 


\section{Macrothink}

\section{Introduction}

Over the years in Nigeria, a greater percentage of secondary school leavers/graduates look forward to gaining access into higher education institutions particularly university institutions. These desires are evident in high demand for admission places and high university enrolment figures. For instance, to create more access to university education, the National Bureau of Statistics (2011) and the National Universities Commission (2010) report that, in Nigeria, the number of universities have increased from 89 in 2006 to 113 in 2011 and university students' enrolment rose from 349,502 in 2002/2003 to 605,068 in 2009/2010 representing 96.01 percent increase in enrolment (Table 1).

Table 1. Total Enrolment in Federal Universities (2002/2003 - 2009/2010)

\begin{tabular}{llc}
\hline YEAR & ENROLMENT & \% INCREASE \\
\hline 2003 & 349,502 & \\
2004 & 419,253 & 19.96 \\
2005 & 450,377 & 7.42 \\
2006 & 765,522 & 69.97 \\
2007 & $1,401,880$ & 83.13 \\
2008 & 661,493 & $(52.81)$ \\
2009 & 577,029 & $(12.77)$ \\
2010 & 605,068 & 4.86 \\
\hline
\end{tabular}

Source: National Bureau of Statistics (2011) and the National Universities Commission (2010)

Currently in Nigeria, there are a total of 113 universities, 75 polytechnics and 88 Colleges of Education. Out of the 113 universities, 36 are Federal, 36 are State and 41 are privately owned universities. Despite the increase in the number of universities, access is not guaranteed; this is because accessibility is primarily a function of the cost of acquiring the education particularly the private cost (out-of -pocket expenditure and opportunity cost). The decision to undertake a bachelor's degree is an expensive investment which has adverse effect on the poor and middle households.

According to Wikipedia (2011), the lower class sometimes referred to as the working class or laboring class describes those employed in lower tier jobs as measured by skills, education and lower income, and the middle class as the class of people in the middle of the societal hierarchy. National Bureau of Statistics (2007), using the expenditure of households per capita and minimum wage rates reveals that the expenditure of low income class is less than 
$\$ 118,304.06$ per annum; the middle class income ranged from $\$ 118,304.06$ to $\$ 225,692.00$ per annum and the upper class income is greater than $\$ 251,789.00$ per annum.

Table 2. Minimum Wage between Low and Middle Classes in Nigeria ( $\$$, 1981-2011)

\begin{tabular}{|c|c|c|}
\hline YEAR & $\begin{array}{c}\text { NOMINAL MINIMUM } \\
\text { WAGE (N) }\end{array}$ & $\begin{array}{c}\text { MINIMUM WAGE OF MIDDLE CLASS } \\
\text { (N) BY INTRAPOLATION AND } \\
\text { EXTRAPLOATION }\end{array}$ \\
\hline 1981 & 125 & 612 \\
\hline 1991 & 250 & 765 \\
\hline 1992 & 363 & 1530 \\
\hline 1999 & 1300 & 2,223 \\
\hline 2000 & 4,000 & $7,960.70$ \\
\hline 2003 & 4,500 & 8,916 \\
\hline 2007 & 11,132 & $22,058.20$ \\
\hline 2010 & 18,000 & $35,986.71$ \\
\hline
\end{tabular}

Source: National Bureau of Statistics (2011)

From Table 2, the minimum wage of the middle class by interpolation and extrapolation is between $\$ 612$ in 1981 and $\$ 35,986.71$ in 2010

Bachelor's degree which is the first level academic degree awarded in different fields in most Nigerian universities requires an average of 4-6years to complete the programme depending on the field of study. For instance, courses such as Management and Administration, Arts, Education, Sciences, Social Sciences, Basic Medical Sciences take an average duration of 4 years; Engineering, Architecture, Law and Pharmacy require an average duration of 5 years while medicine takes average of 6 years for completion with an additional one year of internship training.

Although acquiring bachelor's degree is believed by most individuals, their parents/sponsors to be of substantial economic value, providing more significant job options as well as opportunities for advancement, the private costs also vary by field of study, choice of institution (Federal, State or Private); the individual's life style and on whether the student is a citizen or foreign.

\section{The Problem}

Education is the most effective tool to individual productivity and the key factor to household security in any economy, particularly the Nigerian economy where most good require that the individual possesses at least a bachelor's degree. According to World Bank (2001), 70.2\% of Nigerians live on less than $\$ 1$ per day implying that over $50 \%$ of the populace are poor. 
Given the current minimum wage of $\$ 18,000$, with the escalating price of Bachelor's education, the private cost which includes tuition and other out-of-pocket expenses has risen higher than family income and many households can no longer afford university education. For instance, tuition hike in most public universities have increased between $50 \%$ and over $100 \%$ leading to students protest, suspension of student union leaders and eventual closure of the institutions. Afolabi (2012), Asoma and Oluokun (2011) and Seun (2011) report tuition hike from $\$ 38,000$ (US\$253.33) to $\$ 75,000$ (US\$500) in University of Nigeria, Nsukka, $\$ 49,000$ (US\$326.67) - \$62,000(US\$413.33) in Ambrose Ali University; from between $\$ 30,000$ (US\$200) - \$36,000(US\$240) to $\$ 84,000$ (US\$560) in Anambra State University; $\$ 60,000$ (US\$400) to $\$ 110,000$ (US\$733.33) in Ladoke Akintola University of Technology; from $\$ 120,000$ (US\$800) to $\$ 150,000$ (US\$1000) in Ondo State University, and from $\$ 25,000$ (US\$166.67)- \$30,000(US\$200) to between \$193,750(US\$1291.67) \#348,750(US\$2325) in Lagos State University; with the Federal Government intending to introduce tuition fee of $\$ 180,000(U S \$ 1200)$ per student in Federal universities.(Note: U\$1 to \#150 official rate as 2011 to 2012)

In the same vein, Okebukola (2002) reports the total average unit cost per student per discipline was $\$ 239,402$ (for all science based disciplines) greater than $\$ 186,525$ (for Arts based disciplines) in 2002 and the average unit cost per student per discipline ranged from a minimum of $\$ 141,532$ for Business Administration/Management to a maximum of $\$ 302,096$ for Human Medicine. Whereas, Ofem (2011) found out that the average private unit cost for full-time bachelor's degree programme per student per discipline in public university in 2007/2008 was $\$ 193,170.15$ with a minimum average private unit cost of $\$ 175,536.26$ for Education courses and 262,733.95 for College of Medicine.

With these continuous increases in the private costs of university education, there is the need for an update knowledge of the average private cost of bachelor's programmes by major field as this is believed will provide a better overall picture of bachelor's education which will help the individuals and their parents to plan effectively towards their courses of interest, particularly the fields which will help them achieve their individual goals. It is against this background that this study analyses the private cost of bachelor's degree programmes by major fields.

\section{Literature Review}

\subsection{Theoretical Anchorage}

This study is anchored on the theory of demand which assumes that the quantity of goods demanded is a function of the price with other factors being held constant. Hence it reveals the direct and indirect relationship between the price and the amount consumers are willing and are able to pay; holding consumer income effect, a substitution effects, consumer preferences effects and consumer's expectations effects constant. Extending the demand theory to education in this study, decision to demand for bachelor's education is voluntary decision; hence, the quantity demanded is a functional relationship of the individual's desire/willingness/ ability to acquire bachelor's education and the price(costs) thereof, particularly the private cost (out-of-pocket costs and the indirect cost of earnings foregone 
while acquiring the education).This is primarily because different fields of study of bachelor's education vary in their private costs.

\section{Indices of Private Cost of Education}

Generally, the private cost of education refers to the cost borne by the individual students, parents/guardians. Campbell and Brown (2002) define personal cost or private cost as costs borne by the beneficiaries.

In education, the private cost is further divided into two components namely: direct private costs and indirect private costs. Direct private costs of education are the actual expenditures by the individuals or their parents for providing education, while indirect private costs refer to alternatives forgone by the individuals for deciding to acquire education such as foregone income and student's time. Simply put, this is the opportunity cost of education which represents the real cost of education.

Common indices of private cost of education, bachelor's programmes inclusive are tuition fees, levies, books, stationaries, feeding, transportations, and accommodation Also, Belawati (2006) and Mbua (2007) have identified some other private costs of learners to include caution deposits and cost of uniforms for certain learners, administrative charges and costs of internet connectivity personally or via commercial cybercafés. Other factors affecting increase in private cost of bachelor's courses are the change in courses and the extra years spent on completion.

\section{Methodology}

The descriptive survey design was adopted for the study to clearly describe the key phenomenon of the study (the private cost of bachelor's degree). From the population of 7,206 full time bachelor's degree students of the public universities in Lagos State, a sample of 1,441 students which cuts across the various faculties of the two universities was randomly selected through stratified random sampling technique. Also, the Private Cost of University Education Questionnaire (PCUEQ) whose reliability coefficient was 0.98 using Kuder-Richardson(K-21) was used to obtain information on the private cost of bachelor's degree programme incurred by the individuals.

\section{Research Questions}

In this study, the following research questions are addressed:

1. What is the average private cost of bachelor's degree programmes by major fields in 2009/2010 academic year?

2. Are there significant variations in the private costs of bachelor's degree programmes by major fields in 2009/2010 academic year?

\subsection{Research Question 1}

What is the average private cost of bachelor's degree programmes by major fields in $2009 / 2010$ ? 
Table 3. Total and Average Private Costs of Bachelor's Degree Programmes at the University of Lagos (UNILAG) and Lagos State University(LASU) (per Annum, 2009/10) adjusted for wastages

\begin{tabular}{|c|c|c|c|c|c|}
\hline FACULTY & UNILAG (N) & LASU (N) & TOTAL (N) & \begin{tabular}{|c|} 
Average \\
Private cost of \\
Bachelor's \\
Programme \\
(N) \\
\end{tabular} & $\begin{array}{c}\text { \% of Average } \\
\text { Private Cost }\end{array}$ \\
\hline ARTS & $1.17 \mathrm{E}+05$ & $1.24 \mathrm{E}+05$ & $2.41 \mathrm{E}+05$ & $1.21 \mathrm{E}+05$ & 11.83 \\
\hline $\begin{array}{l}\text { ADMINISTRATION / } \\
\text { MANAGEMENT } \\
\text { SCIENCES }\end{array}$ & $8.02 \mathrm{E}+04$ & $9.32 \mathrm{E}+04$ & $1.73 \mathrm{E}+05$ & $8.67 \mathrm{E}+04$ & 8.49 \\
\hline EDUCATION & $5.38 \mathrm{E}+04$ & $6.71 \mathrm{E}+04$ & $1.21 \mathrm{E}+05$ & $6.05 E+04$ & 5.93 \\
\hline ENGINEERING & $7.24 \mathrm{E}+04$ & $8.06 \mathrm{E}+04$ & $1.53 \mathrm{E}+05$ & $7.65 \mathrm{E}+04$ & 7.50 \\
\hline $\begin{array}{l}\text { ENVIROMENTAL } \\
\text { SCIENCES }\end{array}$ & $8.62 \mathrm{E}+04$ & $0.00 \mathrm{E}+00$ & $8.62 \mathrm{E}+04$ & $8.62 \mathrm{E}+04$ & 8.45 \\
\hline LAW & $1.29 \mathrm{E}+05$ & $1.22 \mathrm{E}+05$ & $2.51 \mathrm{E}+05$ & $1.26 \mathrm{E}+05$ & 12.31 \\
\hline SCIENCES & $7.20 \mathrm{E}+04$ & $6.72 \mathrm{E}+04$ & $1.39 \mathrm{E}+05$ & $6.96 \mathrm{E}+04$ & 6.82 \\
\hline SOCIAL SCIENCES & $6.30 \mathrm{E}+04$ & $7.44 \mathrm{E}+04$ & $1.37 \mathrm{E}+05$ & $6.87 \mathrm{E}+04$ & 6.73 \\
\hline PHARMACY & $8.28 \mathrm{E}+04$ & $0.00 \mathrm{E}+00$ & $8.28 \mathrm{E}+04$ & $8.28 \mathrm{E}+04$ & 8.12 \\
\hline $\begin{array}{l}\text { COLLEGE OF } \\
\text { MEDICINE }\end{array}$ & $9.44 \mathrm{E}+04$ & $1.08 \mathrm{E}+05$ & $2.03 \mathrm{E}+05$ & $1.01 \mathrm{E}+05$ & 9.94 \\
\hline $\begin{array}{l}\text { BASIC MEDICAL } \\
\text { SCIENCES }\end{array}$ & $7.50 \mathrm{E}+04$ & $0.00 \mathrm{E}+00$ & $7.50 \mathrm{E}+04$ & $7.50 \mathrm{E}+04$ & 7.35 \\
\hline $\begin{array}{l}\text { SCHOOL OF } \\
\text { COMMUNICATION }\end{array}$ & & $6.67 \mathrm{E}+04$ & $6.67 \mathrm{E}+04$ & $6.67 \mathrm{E}+04$ & 6.54 \\
\hline TOTAL & $9.27 \mathrm{E}+05$ & $8.03 E+05$ & $1.73 \mathrm{E}+06$ & $1.02 \mathrm{E}+06$ & \\
\hline AVEREAGE & $8.42 \mathrm{E}+04$ & $8.92 \mathrm{E}+04$ & $1.44 \mathrm{E}+05$ & $8.50 \mathrm{E}+04$ & \\
\hline
\end{tabular}

Source: Private Cost of University Education Questionnaire (PCUEQ, 2010)

Note: $\mathrm{E}=$ E-Scientific notation (Exponent multiples) of the preceding number by 10 to the $\mathrm{n}^{\text {th }}$ power.

\subsection{Research Question 2}

Are there significant variations in the private cost of bachelor's degree programmes by major fields in 2009/2010 academic year 
Table 4. Summary of One way ANOVA on the Private Costs of Bachelor's Degree Programmes

\begin{tabular}{lllllll}
\hline Group Variation & $\begin{array}{l}\text { Sum of } \\
\text { Squares }\end{array}$ & Df & $\begin{array}{l}\text { Mean } \\
\text { Squares }\end{array}$ & F & P-value & $\begin{array}{l}\text { F critical } \\
\text { value }\end{array}$ \\
\hline Between Groups & 1718387651 & 1 & 1718387651 & 1.319 & 0.264 & 4.325 \\
Within Groups & $2.7362 \mathrm{E}+10$ & 21 & 1302956949 & & & \\
Total & $2.908 \mathrm{E}+10$ & 22 & & & & \\
\hline
\end{tabular}

From the Table 3, the observed/calculated F-value (1.319) is less than the Critical f-value (4.325) at the 0.05 level of significance. This implies that the observed difference in the mean of the data is not statistically significant. Hence, there are no significant variations in the private cost of bachelor's degree programmes by major fields in 2009/2010 academic year.

\section{Results}

- There were variations in the private costs of bachelor's degree programmes by major fields. However, statistically these observed variations were not significant.

- The average private cost $(8.92 \mathrm{E}+04)$ was higher in the State University than Federal University (8.42E+04).

\section{Discussion of Results}

It was found in this study that there were variations in the private cost of Bachelor's programme by major fields. This is in line with the finding of Bolami (2004) which reports a variation in the unit cost of university education by sector, discipline and type of institution.In the same vein, Okuwa (2004) also reports a variation in the private cost of university education with particular reference to gender with parents spending \$460.60 more on their male child than 328.8 on the female child. The observed difference in the mean of the private cost data was not statistically significant implying the difference occurred by chance.

\section{Conclusion / Recommendations}

The importance and the impact of the private costs of bachelor's degree programmes on the social and economic stratification of economic groups (low and high income classes) cannot be over emphasized, as it provides a guide for households' investment decision making. This study therefore, recommends that given the limited resources available to the middle and low income earners, prospective consumers of bachelor's education should effectively plan their investments in fields that will enable them to achieve their set individual objectives and minimize wastages in the education system. Educational investments should target economic development rather than schooling with emphasis on reading and writing. Individuals should invest in those courses that will give them highest rates of return. Furthermore, investment in education should exert a positive multiplier effect on the economy through developing 


\section{Macrothink}

Journal of Studies in Education

ISSN 2162-6952

2012, Vol. 2, No. 2

appropriate skills in education consumers hence, investment in those courses satisfying the yearnings of education consumers and the economy is crucial.

\section{References}

Afolabi, A. (2008). Varsity Students protest increase in tuition fees. The Nigerian Observer, January 8. http://www.nigerianobservernews.com/16102008/news/national/news7.html

Asoma, I., \& Oluokun, J. (2011, December 22). LASU students get payment deadline extension. Vanguard. Retrieved January 5, 2012 from http://www.vanguardngr.com/2011/12/lasu-students-get-payment-deadline-extension/

Campbell, H.F., \& Brown, R.P.C. (2002). Benefit-cost analysis: financial economic appraisal using spread sheet. United Kingdom: Cambridge University Press.

Balami. (2004). Financing education in Nigeria. In G.A.E Makojio, R.Nwangwu and D.C. Tylor (Eds). The financing of education in Nigeria. Education Sector Analysis. Abuja.

Belawati, T. (2006). Financial Management System in Open and Distance Learning: An example of Universitas Terbuka. Educom. Asia. 12(1), 26.

National Bureau of Statistics. (2011).2011 Annual socio-economic report. Retrieved January 20, 2012 from http://www.Nbs

National Bureau of Statistics. (2007). The Middle Class in Nigeria: Analysis of Profile, Determinants and Characteristics (1980-2007). National Bureau of Statistics.

Ofem, I.B (2011). Cost benefit analysis of public university education in Lagos State, Nigeria. Unpublished Ph.D Thesis. Lagos State University, Lagos, Nigeria.

Seun, L. (2011). Fee Wars hit Campuses. Retrieved January25, 2012 from http://www.Naijacampus.com.ng 